\title{
GENEALOGIA E FISIOLOGIA DO NIILISMO
}

\author{
Maikon Chaider Silva Scaldaferro ${ }^{1}$ \\ Universidade do Estado do Rio de Janeiro (UERJ) \\ Instituto Federal do Espírito Santo (IFES)
}

\section{RESUMO:}

O niilismo é um dos principais temas dos escritos tardios de Nietzsche. O filósofo enxergou sintomas de uma visão niilista do mundo na cultura, política, arte, religião e moral do século XIX. Nietzsche recorre a dois "métodos" de interpretação deste fenômeno, a genealogia e a fisiologia. Nosso texto pretende ser uma introdução ao tema, indicando como Nietzsche elabora uma interpretação genealógica e uma interpretação fisiológica do niilismo.

PALAVRAS-CHAVE: Niilismo; Genealogia; História; Fisiologia; Vontade de Poder.

\section{GENEALOGY AND PHYSIOLOGY OF NIHILISM}

\begin{abstract}
:
Nihilism is one of the main themes of the later writings of Nietzsche. The philosopher saw symptoms of a nihilistic view of the world in culture, politics, art, religion and morality of the nineteenth century. Nietzsche uses two "methods" of interpretation of this phenomenon, the genealogy and physiology. Our text is intended to be an introduction to the issue, indicating how Nietzsche draws a genealogical interpretation and physiological interpretation of nihilism.
\end{abstract}

KEYWORDS: Nihilism; Genealogy; History; Physiology; Will to Power.

\footnotetext{
${ }^{1}$ Doutorando em Filosofia na Universidade do Estado do Rio de Janeiro (UERJ), Rio de Janeiro Brasil e professor do Instituto Federal do Espírito Santo (IFES), Espírito Santo - Brasil. E-mail: maikonhotmail@com.br
}

SCALDAFERRO, Maikon Chaider Silva. Genealogia e fisiologia do niilismo. Griot : Revista de Filosofia, Amargosa, Bahia, v.16, n.2, p.11-24, dezembro/2017. 
O niilismo é um dos principais temas tratados por Nietzsche em seus trabalhos produzidos entre 1882 e 1889. O tema é abordado de maneira totalmente assistemática, disperso em diferentes aforismos. Aparentemente a notória obra não finalizada de Nietzsche, $A$ vontade de poder, que postumamente foi publicada por Peter Gast e Elizabeth Förster-Nietzsche ${ }^{2}$, iria dar uma abordagem mais consistente ao tema. ${ }^{3} \mathrm{O}$ conjunto de aforismos que iriam integrar tal obra não constituem uma investigação ordenada. Contudo, nossa proposta é mostrar como Nietzsche ensaiou nos escritos da década de 80 , a última fase de sua produção filosófica, uma investigação acerca da genealogia e a fisiologia do niilismo.

Nosso texto pretende oferecer uma introdução a esse que um dos assuntos mais relevantes dos últimos escritos do filósofo. Para isso, num primeiro momento apontaremos o que é isto que Nietzsche chama de niilismo (1). Posteriormente, esclareceremos em que consiste as duas formas de investigação do niilismo utilizadas por Nietzsche, a genealogia (2) e a fisiologia (3). Em seguida, mostraremos como Nietzsche constrói uma genealogia (4) e uma fisiologia do niilismo (5).

\title{
O niilismo europeu
}

Nietzsche observou as transformações culturais ocorridas na Europa em do século XIX com bastante pessimismo. O filósofo julgava que havia no século XIX um crescente estado coletivo de indiferença perante a existência. Por todas as partes do velho continente se desenvolvia a compreensão de uma falta de sentido da existência. Os valores que davam significação para o mundo ocidental caíram em descrédito, com isso,este humano passou a ser visto destituído de sentido. Isso porque tais valores eram tidos como os únicos que conferiam sentido ao mundo. A desvalorização dos valores supremos que conduz a uma crescente desvalorização da vida é o acontecimento histórico que Nietzsche denomina niilismo europeu.

O niilismo europeu dispôs o homem moderno num estado de prostração.

\begin{abstract}
Sintomas desse estado de prostração podem ser detectados, segundo Nietzsche, em todos os setores da moderna vida social: na arte, plenamente instrumentalizada para fins de entretenimento, ou, como o chamaríamos atualmente, capturada nos circuitos da indústria cultural; na política e na educação, empenhadas em estabelecer e perpetuar um ideal de homem completamente adaptado aos modos de produção e reprodução de uma sociedade de massas; na moral, na ciência e na filosofia, que se tomaram expressões ideológicas desse desejo de rebaixamento e nivelação da humanidade, agenciado em escala planetária (GIACÓIA, 2000, p. 65).
\end{abstract}

\footnotetext{
2 Hoje nas obras completas de Nietzsche organizadas por Giorgio Colli e Mazzino Montinari, a Vontade de Poder não aparece mais como uma obra. Os aforismos que estavam na versão publicada por Peter Gast e Elizabeth Förster-Nietzsche integram hoje um acervo de aforismos póstumos. Embora a obra não exista, os aforismos que se encontram na versão brasileira de $A$ vontade de poder (da qual nos serviremos para fazer algumas citações) são de Nietzsche, e encontram-se nesse acervo de aforismos póstumos.

3 No aforismo 27 da Genealogia da Moral Nietzsche disse que em sua obra $A$ vontade de poder iria desenvolver um estudo do niilismo "[...] com maior profundidade e severidade (sob o título de 'História do niilismo europeu' [...])" (NIETZSCHE, 1998, p. 146).
} 
Mesmo Nietzsche chamando de niilismo europeu esse acontecimento histórico que surge na modernidade tardia, o filósofo não restringia a área de influência desse evento, bem como o desenvolvimento dele, ao espaço geográfico da Europa. Isso fica bem claro quando Nietzsche afirma:

Quem para farejar possui não apenas o nariz, mas também os olhos e ouvidos, sente em quase toda parte aonde vai atualmente, algo semelhante a um ar de hospício, a um ar de hospital - falo, naturalmente, das áreas de cultura do homem, de toda espécie de "Europa" sobre a terra (NIETZSCHE, 1998, p. 111).

Com a expressão "toda espécie de Europa sobre a terra", Nietzsche quer indicar todas as partes do globo que assimilaram em sua cultura os valores superiores que fundamentaram a civilização européia. Na medida em que tais valores estão sujeitos a uma desvalorização, "toda espécie de Europa" está sujeita ao niilismo.

Para Nietzsche, a grande tarefa para os próximos séculos seria a superação da existência esmorecida na qual o homem moderno se encontrava. Encontrar uma via que desvie a modernidade do niilismo exige a compreensão desse fenômeno que acometeu os indivíduos do século XIX. Nietzsche busca entender o vir-a-ser histórico do niilismo, através da análise das condições fisiológicas que proporcionaram o desenvolvimento deste evento. Nossa hipótese é que o projeto de Nietzsche era realizar uma análise genealógica e uma fisiológica do niilismo. Cabe entendermos como Nietzsche compreende a genealogia e a fisiologia como métodos de investigação.

\section{Interpretação genealógica}

Nietzsche tencionou em sua filosofia construir um modo de investigação que se diferenciasse dos adotados até então pela tradição metafísica. $O$ procedimento genealógico foi considerado por Nietzsche uma alternativa. Para o filósofo, é predominante entre os pensadores da tradição metafísica uma falta de sentido histórico e o ódio a noção de mudança, de devir. Nietzsche diz o seguinte a respeito dessa postura adotada pelos filósofos: "Eles acreditam fazer uma honra a uma coisa quando a des-historicizam, sub specie aeterni [sob a perspectiva da eternidade] quando fazem dela uma múmia" (NIETZSCHE, 2006, p. 25). Expliquemos. A tradição metafísica se desenvolveu desde a busca de um em-si, isto é, uma essência das coisas. Assim, se existem várias concepções históricas do belo, do bem, da verdade, os metafísicos se propuseram a conhecer a essência do belo, do bem e da verdade. Para a tradição metafísica, essas essências não podem ser reduzidas a nenhum dos modos históricos como se compreende (e se compreendeu) tais conceitos. As essências devem ser encontradas em uma realidade imutável, e não na história que é o campo da mutabilidade, do devir. A história é o mero palco da aparência, do erro. Na tradição metafísica o conhecimento da justiça, do belo, do homem, de Deus, da verdade, enfim, de todos esses temas que a filosofia sempre se dedicou, exige um distanciamento da história. Esta só oferece um mundo de aparências. É por isso que Nietzsche considera que a tradição metafísica lidou apenas com conceitos-múmia. 
Para fazer frente à maneira como a tradição metafísica conduziu suas investigações, Nietzsche substituiu a questão "o que é?", pela questão "como é?". Destarte, em vez de perguntar, por exemplo, o que é a justiça, Nietzsche entendeu que se devia investigar como que surge historicamente uma determinada compreensão do justo.

Para Nietzsche, os fatos observáveis no mundo não têm essências imutáveis, não existe um em-si por detrás do mundo das aparências. Os fatos têm valor não essências. Com a noção de valor, Nietzsche quer indicar que a compreensão da realidade se dá sempre a partir de uma interpretação constituída historicamente, e não a partir de uma ascese que eleva o indivíduo até uma realidade suprassenssível.

Na medida em que os fenômenos têm valores (e não essências), Nietzsche propôs que a filosofia devia buscar "[...] um conhecimento das condições e circunstancias nas quais [os valores] nasceram se desenvolveram e se modificaram [...]" (NIETZSCHE, 1998, p. 12). A genealogia é o procedimento apresentado por Nietzsche como sendo adequado para a constituição de tal conhecimento. Com o procedimento genealógico o filósofo pretende explicar determinado fenômeno partindo da

[...] reconstituição dos momentos constituídos de seu vir-a-ser, de tal maneira que o sentido atual desse fenômeno não pode ser obtido sem o conhecimento da série histórica de suas transformações e deslocamentos (GIACOIA, 2000, p. 46).

Ao buscar desestruturar o pensamento metafísico, Nietzsche precisou, enquanto genealogista, "[...] da história para conjurar a quimera da origem" (FOUCAULT, 2000, p. 19). Pois, a história possibilita a ele mostrar que, a própria noção de uma origem que seja o fundamento imutável da realidade, foi algo que surgiu a partir de uma determinada valoração do mundo, isto é, desde uma interpretação dos acontecimentos.

Tendo em vista esse procedimento genealógico que orienta o pensamento de Nietzsche, podemos afirmar que quando o filósofo busca compreender o niilismo a pergunta que ele levanta é: como se dão as condições históricas para o desenvolvimento do niilismo? Pretendemos dar uma resposta a essa questão apontando o processo de investigação de Nietzsche que chamaremos de genealogia do niilismo. Nietzsche nunca escreveu uma obra chamada Genealogia do Niilismo, tal como escreveu uma Genealogia da Moral, entretanto, o modo dele abordar esse fenômeno é em parte genealógico. O filósofo não buscou explicar o niilismo através de essência transmundana causadora de tal evento, mas a partir do seu vir-a-ser histórico.

\section{Interpretação fisiológica}

O Nietzsche genealogista pretendeu superar a forma "desistoricizada" como o pensamento metafísico conduziu as questões filosóficas. Entretanto, a investigação nietzschena não se limita a genealogia. A "interpretação genealógica" é complementado por um "interpretação fisiológica". Na Genealogia da Moral o filósofo afirmou que todo valor conhecido "[...] na história [...] necessita primeiro uma clarificação e interpretação fisiológica [...]" (NIETZSCHE, 1998, p.46). 
O termo fisiologia aparece nos escritos tardios de Nietzsche fazendo referência a conteúdos semânticos diversos. Müller-Lauter identificou ao menos três usos diferentes do termo ${ }^{4}$. A primeira acepção do termo fisiologia presente nos escritos de Nietzsche é a mesma utilizada nas ciências naturais no século XIX. Ou seja, a fisiologia é entendida como ciência que estuda o funcionamento dos seres vivos, isto é, os processos físico-químicos que ocorrem nas células, tecidos, órgãos, etc. Vemos essa compreensão do termo fisiologia no seguinte aforismo do Anticristo: "No tocante aos animais, foi Descartes quem, com audácia admirável, primeiramente ousou compreender o animal como máquina: toda a nossa fisiologia se empenha em demonstrar essa tese" (NIETZSCHE, 2007, p. 19). Nietzsche sustenta que a fisiologia enquanto ciência que estuda o funcionamento dos seres vivos foi condicionada pela compreensão cartesiana de que o corpo funciona como um autômato.

Nietzsche também faz uso do termo fisiologia em um segundo sentido. Fisiologia diz respeito ao somático como o que determina fundamentalmente o ser humano. "O conceito remete, com frequência, às funções orgânicas ou ao afetivo no sentido do imediato corpóreo" (MÜLLER-LAUTER, 1997, p. 22). O corpóreo (isto é, o fisiológico) é o que há de essencial no homem, e por isso precisa ser cuidado. Daí que Nietzsche baseando-se em suas vivências afirme em sua autobiografia: "alimentação, lugar, clima, [...] são, para além de todos os conceitos, mais importantes do que tudo o que se deu importância até agora" (NIETZSCHE, 1978b, p. 373). Cabe ressaltar que o fisiológico enquanto o que é corpóreo não deve ser entendido como o oposto do psíquico. Para tornarmos isso claro é interessante registrar que a língua alemã tem duas palavras para o que chamamos de corpo: der Leib e der Körper. A primeira é utilizada para representar um corpo animado (ou seja, um corpo que possui uma alma), com movimento próprio, como, por exemplo, um homem ou um animal. Já a segunda serve para indicar um corpo inanimado, por exemplo, uma pedra. Heidegger nas suas lições sobre a filosofia de Nietzsche explica que o fisiológico como sinônimo de corpóreo deve ser entendido na dimensão semântica do termo der Leib. Portanto,

quando Nietzsche diz fisiologia, ele tem em vista, com efeito, de maneira acentuada, o estado corporal. Todavia, estado corporal já é sempre em si algo psíquico; portanto, também coisa da psicologia (HEIDEGGER, 2002, p. 88).

O terceiro uso que Nietzsche faz do termo fisiologia mantém uma relação intrínseca com a noção de vontade de poder. Nietzsche entende por vontade de poder (ou vontade de potência) a dinâmica de autossuperação de si, de impulsos para o crescimento. Nietzsche em seu pensamento tardio desenvolve a noção de que a dinâmica da "[...] própria vida é vontade de potência [...]" (NIETZSCHE, 1992, p. 271). Com esse terceiro uso do termo, Nietzsche indica que os processos fisiológicos são "lutas por crescimento". Deste modo, é possível ao filósofo afirmar que "onde, de

4 Sobre o conceito de fisiologia na obra de Nietzsche conferir: MÜLLER-LAUTER, "Décadence artística enquanto décadence fisiológica. A propósito da crítica tardia de Nietzsche a Richard Wagner". Cadernos Nietzsche, 6. São Paulo: Humanitas, 1999; HEIDEGGER, M. Nietzsche, vol. 1. Rio de Janeiro: Forense Universitária, 2007. 
qualquer forma, declina a vontade de poder, há sempre um retrocesso fisiológico também, uma décadence" (NIETZSCHE, 2007, p.22). A partir dessa relação entre fisiologia e vontade de poder, não é possível mais compreender o fisiológico meramente no sentido do corpóreo (der Leib). O termo fisiologia agora abarca "não apenas corpos vivos, mas também o âmbito inorgânico e das produções humanas, tais como Estado, religião, arte, filosofia, etc." (FREZZATTI JUNIOR, 2005, p. 117). Pois, nesses âmbitos também há uma dinâmica de autossuperação e degeneração. Por exemplo: Nietzsche chega a se referir ao Estado moderno como um estado doente, vítima de uma degeneração fisiológica, ou seja, trata-se de um Estado onde se diminuiu a "luta por crescimento".

Para se compreender o que chamaremos de interpretação fisiológica do niilismo é preciso ter em vista os três significados supracitados do termo fisiologia. Pois, tais significações se interrelacionam quando Nietzsche propõe a clarificação e interpretação fisiológica de um fenômeno. Por exemplo, quando Nietzsche realiza a averiguação fisiológica de algo, ele pretende constituir um saber sobre o funcionamento de um organismo visando identificar alterações ou "anormalidades" (aqui se encontram os dois primeiros significados do termo fisiologia). Entretanto, as alterações ou "anormalidades" dos processos fisiológicos são para Nietzsche gradações da vontade de poder. Uma investigação fisiológica pretende explicar as gradações da vontade de pode em diversos âmbitos da realidade (política, cultura, arte, moral, religião, ciência), visto que a vida é vontade de poder (aqui a terceira acepção de fisiologia se une as outras duas).

Podemos dizer que a filosofia de Nietzsche nutre-se de dois modos de investigação: um genealógico e outro fisiológico. A genealogia possibilita um saber acerca das condições históricas que proporcionaram o advento de um determinado valor. Já a fisiologia proporciona um conhecimento dos estados fisiológicos, ou seja, uma conhecimento da gradação da vontade de poder. Assim, a interpretação fisiológica busca explicar o "porquê" que certos valores surgiram em determinados momentos históricos.

\section{Genealogia do niilismo}

O niilismo europeu é um evento que se desenvolve modernidade. Entretanto, Nietzsche sustenta que as condições de possibilidade do niilismo remontam à Antiguidade. Sua genealogia do niilismo europeu procura recuperar dois momentos históricos da antiguidade: 1) o aparecimento da filosofia de Sócrates e Platão 2) o surgimento do cristianismo. A partir desses eventos o genealogista pretende identificar as condições históricas para o desenvolvimento do niilismo no mundo moderno.

Como mencionamos anteriormente, Nietzsche entende que o niilismo começa a ganhar forma na modernidade quando ocorre uma desvalorização dos valores supremos que "regiam" o mundo ocidental. Segundo Nietzsche, Sócrates e Platão deram início à elaboração dos valores supremos do ocidente quando julgaram que a vida não tinha valor (Cf. NIETZSCHE, 2006, p. 17). No diálogo platônico Fédon, Nietzsche encontra os motivos para essa interpretação que ele faz de Sócrates e Platão. No diálogo platônico, Sócrates se refere ao corpo como uma prisão da alma. 
E quando está prestes a morrer fala para Críton: "[...] devemos um galo a Asclépio; não te esqueças de pagar essa dívida" (PLATÃO, 1991, p. 126). Os gregos davam oferendas para Asclépio, o deus da medicina, depois que se era curado de alguma doença. Para Nietzsche, com essa fala Sócrates está se referindo a vida como uma doença que encontra sua cura na morte.

Platão teria sido influenciado por essa visão negativa da vida instaurada por Sócrates. A filosofia platônica parte do pressuposto de que o corpo é mutável e está sujeito ao devir da própria vida, enquanto a alma é imutável e imortal. Sendo assim, o corpo não é um instrumento seguro para o conhecimento humano, somente a alma que permanece sempre igual. Diante disso é preciso que a alma, a razão, subjugue o corpo para o homem conhecer a realidade. De acordo com Nietzsche, o postulado do platonismo diz

[...] É preciso imitar Sócrates e instaurar permanentemente, contra os desejos obscuros, uma luz diurna - a luz diurna da razão. É preciso ser prudente, claro, límpido a qualquer preço: toda concessão aos instintos, ao inconsciente, leva para baixo (NIETZSCHE, 2006, p. 22).

Se o corpo é o lugar do erro e da mentira, esse mundo só nos oferece uma aparência, visto que dependemos do nosso corpo para conhecer as coisas. Para se alcançar o conhecimento da verdade e o agir correto é preciso desviar-se de tudo que é sensível (corpóreo/ fisiológico) e voltar-se para um mundo além da sensibilidade. Através da razão eu atinjo esse mundo verdadeiro suprassenssível. Em termos platônicos, a alma contempla as idéias. "O mundo verdadeiro, alcançável para o sábio, o devoto, o virtuoso [...]" (NIETZSCHE, 2006, p. 31), é estabelecido como o paradigma a partir do qual é possível valorar o mundo. $O$ bem, o verdadeiro, o perfeito, o belo é tudo aquilo que se opõe a sensibilidade. Com o conceito Deus, os cristianismo buscará representar uma síntese do bem, do belo, do justo e perfeito. $O$ que Nietzsche chama de "valores supremos" que vigoraram no ocidente são esses conceitos, essas ideias, colocadas num mundo verdadeiro suprassenssível, que serviram de parâmetro para se compreender a existência.

Sócrates e Platão colocaram esses "valores supremos" num "além" suprassensível que se atinge ao se evitar os desejos, o carnal, o corpóreo. Com o cristianismo o acesso a tais valores deixou de ser algo restrito a uma elite. $\mathrm{O}$ mundo verdadeiro se tornou acessível a todos e não só a alguns "homens sábios". Daí que Nietzsche afirme que "[...] o cristianismo é platonismo para o povo [...]" (NIETZSCHE, 1992, p.8). O cristianismo abriu essa via de acesso para o mundo verdadeiro através da moral. A moral cristã formulou a necessidade de negação da sensibilidade, a aniquilação das paixões, dos impulsos sexuais. Através dessa abnegação de tudo que é sensível o cristão é recompensado com o além, um mundo suprassenssível que o espera depois da morte. Neste mundo ele vive junto ao bem, ao justo, o perfeito e o belo, ele vive junto a Deus.

A história do Ocidente compreendida como vigência dos valores supremos, sofre uma grande transformação com um acontecimento que se desenvolve no interior da modernidade. No livro quinto da Gaia Ciência, Nietzsche descreve da seguinte maneira esse acontecimento: "O mais importante dos recentes acontecimentos - o fato de 'que Deus está morto', de que a fé no Deus cristão está 
enfraquecida, começa já a projetar na Europa suas primeiras sombras" (NIETZSCHE, 1976, p. 225). O advento do niilismo na Europa tem como essencial esse acontecimento histórico que Nietzsche descreveu como a morte de Deus.

Heidegger explica que "no dito 'Deus morreu', o nome Deus, pensado essencialmente, designa o mundo supra-sensível [sic] dos ideais, que contêm as metas para esta vida, existentes acima da vida terrena [...]" (HEIDEGGER, 2007, p. 254). Diante disso, a morte de Deus não deve ser reduzida a um fenômeno no qual as pessoas perdem a fé e param de freqüentar igrejas. A morte de Deus é a perda da crença de que podemos avaliar esse mundo tomando como parâmetro outro mundo num além suprassensível. $O$ enfraquecimento da fé de igreja é só uma conseqüência desse fenômeno maior.

No famoso aforismo 125 da Gaia Ciência, a personagem "o homem louco" diz o seguinte a respeito da morte de Deus: "Os deuses também se decompõem! Deus morreu! Deus continua morto! E nós o matamos!! Como nos consolaremos, nós, os assassinos dos assassinos?" (NIETZSCHE, 1976, p. 133). Vemos que a morte de Deus é algo levado a cabo pelas mãos dos homens. Nietzsche quis apontar que a morte de Deus se deu com a guinada antropocêntrica ocorrida na história européia. $O$ processo histórico iniciado no final da Idade Média e consolidado no início da Modernidade colocou o humano no centro do universo. A humanidade matou Deus e se colocou no lugar dele. Com a morte de Deus

\begin{abstract}
a fuga do mundo para o supra-sensível [si] é substituído pelo progresso histórico [historischer Fortschritt]. A meta do além de uma glória eterna transforma-se na felicidade terrena da maioria. A prática do culto religioso é rendida pelo entusiasmo de criar uma cultura ou da propagação da civilização. O que é criador, o que antes era próprio do Deus bíblico, tornase na marca do fazer humano (HEIDEGGER, 2007, p. 255).
\end{abstract}

Quando a humanidade busca assumir o lugar deixado por Deus, faz isso por não suportar o vazio que se instaura ao perder aquele âmbito da realidade que servia de parâmetro para a valoração do mundo. Com isso, o reino de Deus, isto é, o mundo suprassensível, justo, belo e perfeito, configurou-se como um objetivo a ser realizado neste mundo. Essa nova compreensão acabou propiciando o surgimento da ideia que a história é um progresso, a felicidade é terrena e realizável por meio das "mãos humanas".

Do século XVII até o século XVIII a confiança do homem na razão ainda era o reflexo da tentativa de tronar concreto historicamente aquele mundo suprassensível perfeito, belo e bom. Entretanto, Nietzsche está convicto que esse otimismo não é mais predominante no seu século. "O século XIX é [...] fraco na vontade, triste e sombriamente anelante, fatalista" (NIETZSCHE, 2008, p. 71). Robert B. Pippin observa que

[...] as imagens de Nietzsche da modernidade são imagens fisiológicas de uma final e decisiva exaustão e doença, "sintomas" que finalmente permitem um diagnóstico correto [da modernidade] (PIPPIN, 2006, p. 256, tradução nossa). 
A visão de que a história tenha um télos onde se alcança a realização de uma vida plena começou a desmoronar no século XIX. Em vez de a história ser um progresso para o reino de Deus na terra, o que se vê é "[...] a tortura de uma tensão, que cresce de década a década, como se estivesse encaminanhdo-se para uma catástrofe: inquieta, violenta, precipitada [...]" (NIETZSCHE, 2008, p. 23). A história e a existência humana passa a ser caracterizados como um fluxo permanente sem fim e sentido regidos pelo acaso. Na medida em que o que conferia significado a esse mundo era outro mundo, e este último se mostrou falso, o homem do XIX começa ver tudo como destituído de significado. Tudo é "em vão". Depois da morte de Deus vem a morte da esperança de que a humanidade é Deus. Diante desse quadro a vida é compreendida como não valendo a pena ser vivida. Essa é a caracterização do niilismo europeu feita por Nietzsche.

Nietzsche defende que o advento do niilismo na Europa do século XIX é um fenômeno inevitável. Pois os valores que engendraram a história ocidental já haviam promovido a desvalorização do mundo e da existência humana. Porém, antes havia a possibilidade de se atribuir algum significado ao mundo e à existência a partir da ideia de um outro mundo. Estes seriam um meio, um caminho necessário a se percorrer para alcançar o "reino de Deus". Quando se descobre que esse outro mundo é uma fábula passa-se a ver o único mundo real como desprezível, e a existência como um fardo.

\section{Interpretação fisiológica do niilismo}

A investigação nietzschiana do niilismo estabelece um trabalho de cooperação entre o interpretação genealógico e interpretação fisiológica. Mas como Nietzsche concebe isso? Araldi observa que assim

[...] Nietzsche elabora sua tese fundamental para a compreensão do niilismo: o niilismo tem suas raízes na Antiguidade (em Sócrates, Platão e no cristianismo) devido a uma doença da vontade, fisiologicamente condicionada [...] (ARALDI, 1998, p. 87).

Cabe entendermos quais seriam essas "condições fisiológicas" que proporcionaram o desenvolvimento dos "valores" superiores, e posteriormente a desintegração desses valores. Nietzsche considerou os juízos de Sócrates e Platão acerca do mundo como sintomas de uma vida em declínio. A filosofia socráticoplatônica é a manifestação de um degeneração fisiológica, ou seja, uma diminuição da vontade de poder. Diante disso, um mundo que é sujeito a transformação, ao crescimento e ao perecer, se tornou um incômodo para eles. Na medida em uma diminuição da vontade de poder, o mundo sujeito ao devir torna-se insuportável, projeta-se a ideia de um mundo verdadeiro, um além estável, sem mudanças, no qual não é possível a autossuperação e o crescimento. $O$ mundo do devir é rejeitado. Segundo Nietzsche, "não há sentido em fabular acerca de um 'outro' mundo, a menos que um instinto de calúnia, apequenamento e suspeição da vida seja poderoso em nós: nesse caso, vingamo-nos com a fantasmagoria de uma vida outra, melhor" (NIETZSCHE, 2006, p. 29). Nietzsche vê Sócrates e Platão sofrendo de uma degeneração fisiológica, ou seja, eles não suportam que a dinâmica da realidade seja 
a vontade de poder. Desse modo, para compensar suas fraquezas, eles projetaram a ideia de um mundo suprassenssível, onde não há vontade de poder, pois, tudo se mantém sempre idêntico.

Na Genealogia da moral Nietzsche vai argumentar que o ódio à vida dos degenerados fisiologicamente se tornou uma rebelião dos escravos. A rebelião dos escravos seria o processo de cristianização do mundo que promoveu a degeneração fisiológica em indivíduos saudáveis. Essa rebelião é conduzida por meio da moral cristã. Os fracos passaram a qualificar o que busca crescer como mau, com isso os fortes começaram a se sentirem culpados por buscarem a autossuperação e o crescimento, interiorizando a valoração que os fracos faziam da vida. Assim, os fortes tornaram-se também degenerados fisiológicos, doentes. Esse processo de enfraquecimento dos fortes é para Nietzsche nitidamente observável na Alta Idade Média, com a cristianização dos povos germânicos, classificados como "bárbaros". Nietzsche assim descreve o homem forte (germânico) depois do processo de degeneração promovido pela moral cristã:

\begin{abstract}
Ali jazia ele, doente, miserável, malevolente consigo mesmo; cheio de ódio para com os impulsos à vida, cheio de suspeita de tudo o que ainda era forte e feliz. Em suma, um "cristão"... Em termos fisiológicos: na luta contra a besta, tornar doente pode ser o único meio de enfraquecê-la. Isso compreendeu a Igreja: ela estragou o ser humano, ela o debilitou - mas reivindicou tê-lo "melhorado" (NIETZSCHE, 2006, p. 50).
\end{abstract}

É curioso observar que Nietzsche chega a mencionar que a degeneração fisiológica teve uma curta interrupção na época do Renascimento, que para Nietzsche é a última grande "época forte". Ali a vontade de poder era vista como o princípio vital da existência. Entretanto, o que aconteceu na história depois do Renascimento foi somente degeneração da vontade de poder, décadence. Os lampejos de força que ocorreram na história depois do Renascimento foram demasiadamente fugazes. Segundo Nietzsche, Napoleão e Goethe seriam exemplos desses lampejos (Cf. NIETZSCHE, 2006).

Na modernidade, com a morte de Deus, a vida não mais foi negada em nome de uma promessa de um mundo melhor no além, mas com a promessa da felicidade igual para todos na história. Nietzsche crê que com as correntes igualitárias (democratismo, socialismo, anarquismo) os fracos continuam mantendo os fortes doentes. Todos são nivelados por baixo a partir da afirmação da igualdade entre os homens. Contudo, é no século XIX que o filósofo enxerga o grau máximo da degeneração fisiológica. "O século XIX é [...] fraco na vontade, triste e sombriamente anelante, fatalista" (NIETZSCHE, 2008, p. 71). A vontade de poder se foi reduzida a um nível tão baixo que o niilismo se tornou inevitável. No século XIX os indivíduos negam a vida, mas não mais colocam a fábula de um mundo melhor no lugar. A vida só é depreciada, e nada mais se pretende como isso. Se durante séculos os homens tinham ainda uma vontade de alcançar o nada, no século XIX despontou o desolador quadro de um nada de vontade. Pois, quando os homens buscavam negar a vida atribuindo a ela o valor de nada eles tinham vontade de atingir um mundo verdadeiro, mas este que era um "nada", um "não-ser". Querer atingir um mundo verdadeiro é ainda uma vontade, mesmo que essa vontade seja a 
vontade de depreciar a vida, atribuindo a ela uma nada de valor. "Nada de vontade não é já apenas um sintoma para uma vontade de nada, mas, no limite uma negação de qualquer vontade, um taedium vitae" (DELEUZE, 2001, p. 223), trata-se de um querer não mais querer qualquer coisa.

Embora no século XIX ocorra a plena realização do processo de degeneração fisiológica iniciado na Antiguidade, Nietzsche estima que esse estado de esmorecimento não é permanente. O filósofo chegou a afirmar na Genealogia da Moral que "[...] o homem preferirá ainda querer o nada a nada querer..." (NIETZSCHE, 1998, p. 149). Ou seja, na medida em que a dinâmica da vida é vontade de poder, os homens não conseguem ficar muito tempo sem buscar algo, mesmo que esse algo seja prejudicial à vida. A vontade de crescimento e autossuperação acabam uma hora ou outra ressurgindo. Tendo em vista essa compreensão de Nietzsche, é possível dizermos que junto ao diagnóstico que o autor faz do niilismo no século XIX está uma visão bem hölderliniana de que "onde há perigo, há também salvação". Vejamos o porquê desta nossa hipótese.

Em alguns aforismos publicados postumamente, vemos Nietzsche afirmando que é possível enxergar sinais de fortalecimento dos homens bem no cerne do niilismo. O filósofo diz:

Princípio fundamental: há algo de decadência em tudo o que o homem moderno apresenta: mas, estreitamente junto à doença, estão sinais de uma força ou potencialidade da alma ainda não experimentada. As mesmas razões que produzem o apequenamento dos já mesquinhos impulsionam os mais fortes e mais raros até os píncaros da grandeza (NIETZSCHE, 2008, p. 81).

Na medida em que o niilismo promoveu a desvalorização dos valores supremos, o que aconteceu foi a perda daqueles arquétipos utilizados para valorar o mundo. Deste modo, o niilismo traz a possibilidade disso que Nietzsche chama de "transvaloração de todos os valores". Trata-se não somente de "[...] uma mudança de valores, mas uma mudança no elemento do qual deriva o valor dos valores" (DELEUZE, 2001, p. 256). Em vez de esse elemento ser um "não à vida", como a "tranvaloração de todos os valores" o elemento passaria ser um "sim à vida". O elemento do qual derivaria o valor dos valores seria a vontade de poder, a apreciação da vida e não a depreciação. Apesar de Nietzsche ter feito previsões sobre um longo período de duração do niilismo, ele também avaliou que estavam surgindo condições de possibilidade para uma superação deste nada de vontade. É munido de tal expectativa que o filósofo faz a seguinte afirmação: "A visão do europeu atual encheme de esperança: está em formação uma raça audaz e dominadora [...]" (NIETZSCHE, 2008, p. 468). Quem são esses "bons europeus" não fica muito claro de se identificar nos escritos do filósofo alemão. $O$ que se sabe é que depois da morte de Nietzsche muitos entenderam que a carapuça lhes servia. A história européia do século XX é recheada de exemplos de indivíduos que se utilizaram do prognóstico nietzschiano acerca do porvir de uma nova "raça dominadora". 


\section{Considerações finais}

Nosso trabalho propôs mostrar as duas linhas de investigação seguidas por Nietzsche em seus estudos sobre o niilismo. Ainda que tenhamos distinguido de maneira bem esquemática a interpretação genealógica da fisiológica, essa separação entre os dois procedimentos não aparece nitidamente delimitada na obra do filósofo. Genealogia e fisiologia formam uma amálgama na filosofia nietzschiana, não há genealogia sem fisiologia, ou uma fisiologia sem genealogia. Ao ter em vista a importância dessa relação de complementação mútua entre genealogia e fisiologia, Nietzsche sublinhou o seguinte: "O que faltou aos filósofos? a) sentido histórico, b) conhecimento da fisiologia, c) um alvo voltado para o futuro" (NIETZSCHE, 2008, p. 217).

Com sua filosofia Nietzsche quer fazer uso disso que faltou aos filósofos. O sentido histórico ele buscou ganhar através da genealogia, com ela o filósofo quis mostrar como que as coisas são dotadas de valor não de essências. Já o conhecimento da fisiologia permitiu que a investigação não se reduzisse a um historicismo. $O$ historicismo em suas diversas vertentes pretendia colocar a história como o grande princípio de onde poderia se explicar a conduta humana. Todavia, os historicistas julgavam que a investigação histórica devia ser neutra, desinteressada tendo um fim em si mesmo. O problema do historicismo sempre perpassou toda filosofia de Nietzsche. Ainda na década de 70 o autor procurou mostrar em suas Considerações Extemporâneas que um conhecimento histórico desinteressado (neutro) é como alimentar-se sem fome até causar uma indigestão. Nietzsche afirma o seguinte acerca do uso da história desde o ponto de vista de um historicismo: "há um grau de insônia, de ruminação, de sentido histórico, no qual o vivente chega a sofrer dano e por fim se arruína, seja ele um homem ou povo ou uma civilização" (NIETZSCHE, 1978a, p. 58). Esse desinteresse pregado pelo historicismo pode ser entendido como um sintoma do niilismo.

A partir dessa leitura nietzschiana do historicismo, vemos que ter um conhecimento histórico não é suficiente para as pretensões filosófica de Nietzsche, pois, o excesso de conhecimento histórico sem um interesse acaba por erradicar o impulso para construção de algo novo no futuro. Com isso, "buscando pelas origens, o indivíduo torna-se caranguejo. $O$ historiador olha para trás; por fim ele também acredita para trás" (NIETZSCHE, 2006, p. 13). Para não cair no historicismo Nietzsche pretendeu por a história a "[...] serviço de uma potência a-histórica [...]" (NIETZSCHE, 1978a, p. 60), ou seja, a vida, vontade de poder, isto que o filósofo entende como sendo a dinâmica própria de tudo que existe. Com a fisiologia Nietzsche pretendeu lançar mão de um instrumento que lhe permitisse "[...] cultivar história em função dos fins da vida!" (NIETZSCHE, 1978a, p. 60).

Com a união da genealogia com a fisiologia Nietzsche tinha em vista a possibilidade de se ganhar aquele alvo voltado para o futuro que faltou aos filósofos. Deste modo, uma investigação do niilismo não é só o relato de um historiadorcaranguejo que olha para trás e se lamenta. O diagnóstico do fisiologista Nietzsche quer indicar o caminho para a mudança do quadro histórico que a genealogia lhe ofereceu. Com uma genealogia e uma fisiologia do niilismo, o pensamento de Nietzsche pode ser entendido como uma cabeça de Jano, que olhando para trás ao 
mesmo tempo olha para frente. Por fim, ressaltamos que a interpretação nietzschiana do niilismo suscita algumas questões fundamentais que merecem ser abordadas em outro momento, tais como: Deveríamos adjetivar Nietzsche da mesma forma que ele adjetivou Kant, isto é, como uma raposa que por sua esperteza escapou de uma jaula, mas que depois acaba retornando para ela? ${ }^{5}$ Nietzsche ao colocar a história a serviço de uma potência a-histórica não permanece preso a tradição metafísica que ele tanto despreza? Nietzsche estaria renovando a metafísica a partir da noção de vontade de poder?

\footnotetext{
5 Na Gaia Ciência vemos essa adjetivação de Kant por parte de Nietzsche no seguinte aforismo: "E agora não me venhas falar do imperativo categórico, meu amigo! - essa palavra faz cócegas em meu ouvido, e tenho de rir, a despeito de tua presença tão séria: faz-me pensar no velho Kant, que como castigo por ter-se apossado sub-repticiamente da 'coisa em si' - também uma coisa muito ridícula! foi sub-repticiamente apanhado pelo "imperativo categórico" e com ele no coração extraviou-se e voltou outra vez para 'Deus', 'alma', 'liberdade' e 'imortalidade', igual a uma raposa que se extravia e volta para sua jaula: - e eram sua força e esperteza que haviam arrombado essa jaula!" (NIETZSCHE, 1976, p. 207). Com essa passagem sarcástica Nietzsche quer colocar em oposição as conclusões de Kant na Crítica da razão pura com as da Crítica da razão prática. Enquanto na Crítica da razão pura Kant negou a possibilidade da metafísica se constituir como ciência, pois é impossível um conhecimento acerca de "Deus", "alma", "liberdade", na Crítica da razão prática ele atribui um importante papel a essas ideias, ao passo que elas constituem postulados da razão prática de sujeitos que agem moralmente, isto é, de acordo com o imperativo categórico.
} 


\section{Referências bibliográficas}

ARALDI, C. L. Para uma caracterização do niilismo na obra tardia de Nietzsche. Cadernos Nietzsche, 5. São Paulo: Humanitas, 1998.

DELEUZE, G. Nietzsche e a filosofia. Porto: Rés-Editora, 2001.

FOUCAULT, M. Nietzsche, a genealogia e a história. In: Microfísica do poder. Rio de Janeiro: Graal, 2000.

FREZATTI JUNIOR, W. Nietzsche e a dissolução da dualidade cultura/biologia. In: Azeredo, Vânia D. de (Org.). Falando de Nietzsche. Ijuí: Editora da Unijuí, 2005.

GIACOIA JR, O. Nietzsche. São Paulo: Publifolha, 2000.

HEIDEGGER, M. Caminhos de floresta.Lisboa: Fundação Calouste Gulbenkian, 2002 .

. Nietzsche, vol. 1. Rio de Janeiro: Forense Universitária, 2007.

MÜLLER-LAUTER, W. A doutrina da vontade de poder em Nietzsche. São Paulo: ANNABLUME, 1997.

Décadence artística enquanto décadence fisiológica. A propósito da crítica tardia de Nietzsche a Richard Wagner. Cadernos Nietzsche, 6. São Paulo: Humanitas, 1999.

NIETZSCHE, F. W. Além do bem e do mal. São Paulo: Companhia das Letras, 1992. - A gaia ciência. São Paulo: Hemus, 1976.

- A vontade de poder. Rio de Janeiro: Contraponto, 2008.

Considerações extemporâneas. in: Obras incompletas. Coleção "Os

Pensadores". 2. ed. São Paulo: Abril Cultural, 1978a.

- Crepúsculo dos ídolos, ou, como se filosofa com o martelo. São Paulo:

Companhia das Letras, 2006.

. Ecce Homo. In: Obras incompletas. Coleção "Os Pensadores". 2. ed. São

Paulo: Abril Cultural, 1978b.

. Genealogia da moral. Souza. São Paulo: Companhia das Letras, 1998.

. O anticristo. São Paulo: Companhia das Letras, 2007.

PIPPIN, R. B. Nietzsche's alleged farewell: The premodern, modern, and postmodern Nietzsche. In: The Cambridge companion to Nietzsche. Cambridge: Cambridge University Press, 2006.

PLATÃO. Fédon. In: Obras incompletas. Coleção "Os Pensadores". 5. ed.. São Paulo: Abril Cultural, 1991.

Autor(a) para correspondência: Maikon Chaider Silva Scaldaferro, Instituto Federal do Espírito Santo, Av. Rio Branco, 50, Santa Lucia, CEP 29056-255, Vitória - ES, Brasil. maikonhotmail@com.br 